\title{
SPIRITUAL EDUCATION MISSION IN THE MUFASSIRIN PERSPECTIVE
}

\author{
Syarif \\ IAIN Pontianak \\ Email: zsyarif99@yahoo.co.id
}

\begin{abstract}
Spiritual crisis is a factor leading to disorientation in today's modern humans and the decline of morality of the nation. The low level of spirituality is caused by an educational approach that only focuses on the brain and ignores spiritual values. The Qur'an has actually affirmed the mission of spiritual education which should be used as a reference for the current education system. This article employs library research method through a comparison of the way the mufassirin interpret verses about the mission of spiritual education. The results show that the mission of spiritual education carried out by the Prophet Muhammad can be seen for example in Surat Al-Anbiya' verse 107, Surat Saba'verse 28 and Surat Al-Ahzab verse 21, namely rahmatan lil 'alamin (mercy to all creations). The prophet has brought evidence the truth to perfect the akhlâq, as well as to become the followers of uswah hasanah (perfect example) which must be imitated by all humans. Meanwhile, the stages of increasing spirituality in the Surat Luqman Verses 12-19, include: (1) instilling the tauhid values, (2) being filial to parents, (3) understanding the reciprocity of each deed, (4) command to worship, (5) introducing politeness in social life. Elements of spiritual education contained in Surat al-Muzzammil Verses 1-10 include qiyamul lail or night prayer, reciting the Qur'an in a tartil way, getting used to zikr, patience, jihad $f i$ sabilillah or fighting on the path of Allah, and always praying and begging forgiveness from Allah.
\end{abstract}

Keywords: Spiritual; Education; Mission, Mufassirin.

\section{INTRODUCTION}

Education is basically a media of educating and developing primordial human potential, so it is one of the most important aspects in building the quality of society and nation. ${ }^{1}$ It is assumed to be so because the essence of education is the main gate in the framework of transformation towards a better and more humanistic civilization and culture with the principle of a balance between relations between humans, humans and the environment, and humans with

${ }^{1}$ Masbur, "Integrasi Unsur Humanisasi, Liberasi, dan Transedensi dalam Pendidikan Agama Islam”, in Jurnal Edukasi, Vol.2, Number 1, January 2016, p. 45. 
the Creator. Education is an important process which includes interpersonal and intrapersonal dialectics in the course of human life, both past, present, and future. ${ }^{2}$ Spiritual education here is a conscious effort to foster, guide, develop, and direct students' spiritual intelligence, so that they can become the human beings in accordance with the mission of Islamic teachings. In other words, spiritual education is education in Islam that focuses on the dimensions of spirituality as the main potential in driving every educational and teaching activity. $^{3}$

The spiritual intelligence defined by Ary Ginanjar is the voice of the human heart which is the spiritual key as it becomes the emanation of divine attributes. ${ }^{4}$ The divine nature referred to is contained in 99 Names of Allah or called Asma al-Husna. ${ }^{5}$ If the human heart is cleared of despicable traits, prejudices, experiences, and negative motivation that affect it, then the cleared heart will be able to receive the truth, honesty, or deepest inner voice that can create spiritual intelligence. ${ }^{6}$ Strangely, in the course of time practicing in the field, long-running education has not shown what is expected according to the original education goals. Even worse, education is instead used as a means of indoctrination of negative interests. If the ideals of education can be realized properly, then it needs a system or concept that is able to empower the potential in humans, both intellectual and spiritual potential.

Current education failures require serious attention from all parties, from the lowest to the highest level. The main reason is because at present the morality of the nation's children has deteriorated drastically and is very worrying, for example: rampant brawl ${ }^{7}$, increasing drug abuse ${ }^{8}$, widespread premarital sex among teenagers ${ }^{9}$, we always watch and hear every day. In some coverage in 2012).

${ }^{2}$ Imron Fauzi, Manajemen Pendidikan ala Rasulullah. Yogyakarta: Ar-Ruzz Media,

${ }^{3}$ Limas Dodi, "Nilai Spiritulitas Sayyed Hossein Nasr in Manajemen Pendidikan Islam", Dirasat, Vol.4, Number 1, June 2018, p.70-71.

${ }^{4}$ Ary Ginanjar Agustian, Rahasia Sukses Membangun Kecerdasan Emosi dan Spiritual, ESQ Way 165: 1 Ihsan, 6 Rukun Iman dan 5 Rukun Islam (Jakarta: Arga, 2001), 44

5 Agustian, Rahasia Sukses, 107

${ }^{6}$ Agustian, Rahasia Sukses, 104

7 Quoted from the data provided by the National Commission for Child Protection, data on student brawls in 2010 there were 102 cases, in 2011 there were 96 cases, in 2012 it increased to 147 cases, in 2013 there were 255 cases, up to 2014 as many as 275 cases (see www. kpai.go.id/, accessed on 12/09/2018).

${ }^{8}$ Kasus pengguna narkoba dari tahun 2010 sebanyak 17.898 kasus, tahun 2011 sebanyak 19.128 kasus, tahun 2012 sebanyak 19.081 kasus, tahun 2013 sebanyak 21.269 kasus, tahun 2014 sebanyak 23.134 kasus, tahun 2015 meningkat menjadi 28.588 kasus (see www. bnn.go.id/, accessed on 12/09/2018).

9 Dr. Mawardi revealed that East Java adolescents who have had sex are quite large, namely: Jember as much as $12.1 \%$, Madiun as much as $15.25 \%$, Surabaya as much as $15.0 \%$ and Banyuwangi as much as 19.0\% (Al-Falah Magazine, Edition 174 / September 2002); Dr. 
electronic and print media, it has shown how bad the relationship between teachers and students is. For example, teachers who are supposed to teach akhlâq, instead molest, commit violent acts and discriminate against their students, etc. ${ }^{10}$ Even worse, students also commit violent acts against teachers. ${ }^{11}$ The decline was caused by a spiritual crisis, and education is only a theoretical study, not in the application. Syamsul Kurniawan, assumed that there is a correlation between morality and the quality of one's religiosity (spirituality), given the maturity of one's spirituality can be seen from the quality of his morality. ${ }^{12}$ So, if there is a decline in morality as in the example above, it can be assumed that there is a problem with the quality of one's spirituality. According to Mulyadhi Kartanegara, this spiritual crisis has caused disorientation in today's modern humans. The word disorientation is a negation of orientation, which occurs when a person does not know the direction, has no purpose, does not know where she/he will go, does not even know where she/he comes from. ${ }^{13}$ According to Zohar, the spiritual crisis is a fundamental crisis in society in the modern era. Goleman also explained that in this millennium the "age of melancholy", the $21^{\text {st }}$ century is called the "age of anxiety". Therefore, Zohar considers these modern humans to be spiritually dumb, not only in Western countries, but also in Eastern countries that are increasingly affected

Andik Wijaya said that 95\% of teenagers in Malang had been involved in pornography (http:// sobatmuda.multiply.com//, accessed on 11/09/2018); even the BKKBN also found $97.5 \%$ of students and students in Yogyakarta had lost their virginity and $90 \%$ of them had had an abortion (www.bkkbn.go.id/, accessed on 11/09/2018).

${ }^{10}$ Data released by the KPAI from 2011 to 2016 shows a graph of the increase in the number of violence against children in schools, namely: in 2011 as many as 276 cases; in 2012, 522 cases; in 2013, 371 cases; in 2014, 461 cases; in 2015, 538 cases; and in 2016, 821 cases (http://bankdata.kpai.go.id/, accessed on 01/09/2018).

${ }^{11}$ For example, recently, in early February 2018, a case happened to Achmad Budi Cahyanto, a teacher of SMAN 1 Torjun, Sampang, Madura. He died after being beaten by a student named HZF (Editorial Team, "Beaten by Student, Teacher Died in Hospital", Jawa Pos Edition February 3, 2018, 11); In August 2017 in West Sulawesi, a junior high school student with the initial FR persecuted his class teacher, using wood until the teacher was seriously injured (Joni Banne Tonapa, "Not happy after being scolded, Junior High School Student persecuted the teacher " at https://daerah.sindonews.com/ , accessed 02/092018); November 2016, in Sekayu, AF, a student at Al-Karim Noer Integrated Islamic Junior High School was stabbed the teacher, Kurniasih Alawiyah, 13 times using a knife (Amarullah Diansyah, "Offended, Junior High School Student Stabs Teacher 13 Times" in https: // area .sindonews. com/, accessed 02/09/2018); In August 2016, in Makassar, Dasrul, a teacher at Makassar 2 Vocational High School, was beaten by his own student Sutrisno Zulkifli, “This is Alif’s Lie, Student Beating Vocational School 2 Teacher Version of Classmates”, in http://news.rakyatku. com/, accessed on 04/09/2018).

${ }^{12}$ Syamsul Kurniawan, "Pendidikan Karakter dalam Islam: Pemikiran Al-Ghazali tentang Pendidikan Karakter Anak Berbasis Akhlaq al-Karimah”, Tadrib, Vol.3, Number 2, December 2017, p. 12. 2006), 13

${ }^{13}$ Mulyadhi Kartanegara, Menyelami Lubuk Tasawuf, (Jakarta: Published by Erlangga, 
by the West. ${ }^{14}$

One of the causes of the low spirituality is the education system that only focuses on the brain in the field of science (science and technology), which is only intended to exploit natural resources for external gain, while the moral and spiritual aspects are left empty, so their heart is arid, ferocious, and dry. They are ambitious to spend and destroy everything before them. They experience a crisis of balance between life force, heart power, and thinking power in their lives, which can motivate them to do anything without feeling the slightest shame. This educational process will give birth to new humans who can fulfill nature, but they lose their identity, and cannot understand what life really means. ${ }^{15}$ The educational process that has been running so far is still dominated by issues that are merely cognitive and theoretical. Such education seems less concerned about examining the issues of how to integrate cognitive knowledge with affective and psychomotoric domains, so that it becomes more "meaningful" and "valuable" for students through various approaches, models, strategies, and media. In addition, the "meanings" and "values" that have been instilled and embedded can serve as a principle or source of motivation for students to make decisions, act, and behave in a concrete way in the realm of life praxis. ${ }^{16}$ This is because of the education dichotomy which tends to separate science from its spiritual dimension. This is what is feared by several Muslim scholars such as Ismail Raji al-Faruqi, Syed Muhammad Naquib al-Attas, Fazlur Rahman, Ziauddin Sardar, Kuntowijoyo, Azyumardi Azra, M. Amin Abdullah, Imam Suprayogo, etc., where they all realize the Islamic sources are very concerned about this issue. ${ }^{17}$

According to Quraish Shihab, from the verses of the Qur'an, it can be inferred that changes and improvements in spirituality can occur if two conditions are met, namely (1) the existence of values or principles; (2) the presence of actors who can adapt themselves to these values and principles. The first requirement is the authority of Allah Almighty through the instructions in the Qur'an and the explanation from Prophet Muhammad, although it is still global and general, and it needs details and interpretation of human reasoning. While the second condition, the perpetrators are people who are always bound by

${ }^{14}$ Danah Zohar and Ian Marshal, SQ: Spiritual Intelligence: The Ultimate Intelligence, (Great Britain: Bloomsbury, 1995), 102

${ }^{15}$ Ipah Latipah, "Implementasi Metode Al-Hikmah, Al-Mau’idhah Al-Hasanah, dan Al-Mujadalah dalam Praktik Pendidikan”, Jurnal Ilmiah Mitra Swara Ganesha, Vol. 3 No. 2 (July 2016), 23

${ }^{16}$ Kasinyo Harto dan Abdurrahmasyah. Metodologi Pembelajaran Berbasis Aktive Learning: Arah Baru Pembelajaran PAI di Sekolah dan Madrasah. (Palembang: Grafika Telindo Harto, 2009), 2-3

${ }^{17}$ Syamsul Kurniawan, "Dikotomi Agama dan Ilmu dalam Sejarah Umat Islam dan Kemungkinan Pengintegrasiannya”, in Fikrah, Vol.1, Number 1, January-June 2013, p. 142. 
norms, ethics, morals, and laws agreed upon by the community. ${ }^{18}$ The process of increasing the elements of spiritual intelligence, for example, can be seen in the QS Luqman verses 12-19 and al-Muzammil verses 1-10. In Tafsir alMisbah, QS Luqman is included in the category of Makiyyah surat, which consists of 34 verses, and was revealed after Surat al-Shaffat. Meanwhile, alQurthubi said that QS Luqman belongs to the Makiyyah category, except verses 27-29, because the three were revealed in Medina. ${ }^{19}$ The name of Luqman is derived from the name of a character who is a wise parent figure blessed with hikmah, so that he is also known as al-hakim, which means a wise person. ${ }^{20}$ According to al-Biqa'i, the meaning of hikmah is knowledge of important things. Hikmah can be referred to as scientific charity and religion. Al-Ghazali defined hikmah as the main science, meaning that the main source of knowledge and the greatest form is Allah. Therefore, the essential judge is Allah Almighty. ${ }^{21}$

Hamka said that the word "al-Muzzammil" in the Qur'an surah Al-Muzammil is meant to be a name Allah SWT calling the Prophet Muhammad as a sign of deep love and affection, both in the context when he was awakened from his deep sleep and the context of duties and responsibilities he carried out. ${ }^{22}$ Al-Qurthubi added, the word "al-Muzzammil" was a temporary call on the condition of Prophet Muhammad at that time. The usefulness of this call contains two meanings, namely: first, gentle attitude. The call of "alMuzzammil" implies the meaning of an outpouring of love, affection and tenderness, so that the Prophet did not need to feel worried about anything; second, to give a warning; "Al-Muzzammil" is intended for all Muslims who are sound asleep at night to get up soon, and perform qiyamullail and $d h i k r .{ }^{23}$ From the spiritual education perspective, a person who has spiritual intelligence is the one who is able to feel and give affection. This feeling is not only directed at fellow human beings, but must be prioritized to Allah SWT, then fellow human beings, and other God's creatures. That is why Allah SWT calls Muhammad (pbuh) with the call of affection and at the same time teaching him to have compassion. Because the main mission of spiritual education is to spread rahmatan lil alamin and to form insan kamil (perfect human being), namely the perfection of akhlâq, as the main responsibilities

${ }^{18}$ M. Quraish Shihab, Membumikan al-Quran: Fungsi dan Peran Wahyu dalam Kehidupan Masyarakat, (Bandung: Mizan, 1999), 245-246

${ }^{19}$ Nurwadjah Ahmad, Tafsir Ayat-Ayat Pendidikan (Bandung: Marja, 2007), 154

${ }^{20}$ As'aril Muhajir, Ilmu Pendidikan Perspektif Kontekstual, (Yogyakarta: Ar- Ruzz Media, 2011), 142

${ }^{21}$ See M. Quraish Shihab, Tafsir al-Misbah Pesan Kesan dan Keserasian al-Qur'an, Vol. II (Jakarta: Lentera Hati, 2002), 121

${ }^{22}$ Hamka, Tafsir Al-Azhar, 705

${ }^{23}$ Imam Al-Qurthubi, Tafsir Al-Qurthubi, (Jakarta: Pustaka Azzam, 2009), 420 
of the Prophet Muhammad stated in the Qur'an, for example in Al-Anbiya' verse 107 , Saba' verse 28 , and Al-Ahzab verse 21 . Therefore, it is very urgent for the writer to conduct this study on the mission of spiritual education from the Mufassirin perspective, as well as its relevance to the current education system.

\section{SSPIRITUAL EDUCATION CONCEPT}

Education, from the Islamic perspective, has a high position. This is evident in the meaning of the first revelation received by Muhammad (pbuh) ordering to read in his ummiy condition. ${ }^{24}$ In addition, this revelation also mandates the command to always learn to know Allah SWT, read natural phenomena, and recognize oneself which includes the principles of aqeedah, knowledge, and charity. These three principles are the portals of the mission of spiritual education in Islam. Spiritual education in Islamic teachings is an effort to teach science because it contains scientific and spiritual delights, so one will be able to arrive at the scientific nature and moral values that are commendable, and try to deliver humans to achieve universal or overall personal balance. This can be done through a process of learning and training that involves the soul, mind, intelligence, feelings and senses. Therefore, spiritual education will always strive to develop all the potential in human beings, which includes: intellectuality, imagination, scholarship, as well as spirituality. ${ }^{25}$

In Islam, education occurs throughout the human life span (longlife education), not limited by conditions, space and time. Islam always advocates for humans to always develop the quality of their knowledge and faith, both for men and women, young and old, poor and rich, they all get a portion and justice which is related to the obligation to learn. Nor is it limited to only science related to ukhrowi, but also science is related to worldly issues because human happiness

${ }^{24}$ See QS. Al Alaq (96): 1-5. And about this ummiy condition, there are differences among the scholars. Some say that ummiy is illiterate or being unable to read and write. Some say ummiy is a person who has never read or written the book of God. There are also those who say that ummiy is a person who has a motherly nature, etc. See Sheikh Al Maqdisi. Is Prophet Muhammad Blind or Genius? (Revealing the Mystery of the Prophet's Ummiy Condition). Jakarta: Nun Publisher. 2007

Whereas in interpreting the word iqra', Quraish Shibah stated that the word iqra' is taken from the verb qara'a which at first means to gather. He also explained that the realization of the order does not require that a written text be an object of reading, nor should it be said so that it is heard by others. Gabriel also did not read a written text, because in a history it was stated that the Prophet asked, "maa aqra" (what should I read?). This is different if "maa aqra" is interpreted not as "I cannot read", but it is understood "What should I read?" Thus, Qurasih Shihab believes that the word ummiy does not mean illiteracy or cannot read and write. See Tafsir Al Misbah. Vol. 15: 392

${ }^{25}$ M. Athiyah Al Abrasyi. Dasar-dasar Pokok Pendidikan Islam. Trnaslation by H. Bustami from the original title Tarbiyyah Islamiyah. Jakarta: Bulan Bintang. 1993, 14 
can be achieved if these two paths are fulfilled in a balanced manner. This spiritual education refers to spiritual education in Islam contained in the Qur'an. Education here covers all aspects of the universe, by positioning Allah as an educator of the universe (Rabb al-'alamin). According to Ibnu Manzhur and Asyrof, Islamic education is termed al-tarbiyah, al-ta'lim, and al-ta'dib. ${ }^{26}$ If studied comprehensively in the Qur'an and the sunnah, in fact not only these three words correlate with education. Other words that are similar to education are for example: al-tahdzib, al-muwa'idzah, al-riyadhah, al-tazkiyah, al-tafaqquh, etc. ${ }^{27}$

Al-tarbiyah comes from the word rabba, yarubbu, rabban, which means to lead, and to care for (children). ${ }^{28}$ The word Rabb in the Qur'an is repeated 169 times. For example, the word rabba (educating) can be seen in the Qur'anic verses of Surat al-Isra' [17]: 24; Ash Syua'ara [26]: 18; al-A'raf [7]: 61; and ar-Rum [30]: 39. According to al-Maraghi, al-tarbiyah activities can be divided into two types, namely: (1) Tarbiyah khalqiyyah, which deals with the formation of physical aspects of humans, so that it can be used as a supporting tool in developing aspects of spirituality; (2) Tarbiyah diniyyah tahdzibiyyah, which deals with the development of human morality for spiritual preservation. ${ }^{29}$ Meanwhie, my definition of al-tarbiyyah is summarized as a process of fostering individuals, in the physical, intellectual, emotional, spiritual aspects, which are carried out continuously and integratively to achieve life's perfection. This educational process aims to educate them in living the values that are appropriate to achieve happiness in the world and the hereafter. Education is also called al-ta'lim which comes from the word 'allama, and it connotes learning or the process of transferring knowledge. According to Jalaludin, the word al-Ta'lim could be defined as guidance which emphasizes improving intellectual aspects of students, ${ }^{30}$ as contained in QS. al-Baqarah [2]: 31-32. Meanwhile, Shihab defined the word yuallim as teaching, namely the process of filling students' minds with knowledge about the realms of physics and metaphysics, as in contained QS. Al Jumu'ah [62]: 2. ${ }^{31}$

The word al-ta'dib comes from the word 'addaba, yu'addibu, ta'diban. The word al-ta'dib also comes from the word $a d a b$ which means being civilized

${ }^{26}$ As'aril Muhajir, Ilmu Pendidikan Perspektif Kontektual, 25-26

${ }^{27}$ Abuddin Nata. Ilmu Pendidikan Islam. Jakarta: Prenada Media. 2010, 7

${ }^{28}$ Mahmud Yunus. Kamus Arab-Indonesia. Jakarta: PT. Hidakarya Agung. tt, 136

${ }^{29}$ Ahmad Mustafa Al-Maraghi, Tafsir Al-Maraghi, Juz I, (Semarang: PT. Karya Toha Putra Semarang, 1993), 30, or see Abdul Mujib and Jusuf Mudzakir. Ilmu Pendidikan Islam, (Jakarta: Prenada Media, 2006), 17

${ }^{30}$ Jalaluddin, Teologi Pendidikan, (Jakarta: PT. Raja Grafindo Persada, 2003), 133

${ }^{31}$ Quraish Shihab. Membumikan Al Qur'an, (Bandung: Mizan, 1996), 172 
and polite, ${ }^{32}$ manners, character, morality, and ethics. Nuqaib Al-Attas prefers the word al-ta'dib for thedefinition of education. According to him, al-ta'dib means guidance that is carried out in stages instilled in humans about the good and right things, so that they can guide them toward acknowledging the majesty of God. ${ }^{33}$ After my careful study on the vocabulary related to education and teaching as mentioned earlier, it can be stated that all the words belong to the group of words related to education. Therefore, the nature of education in Islam has a very broad meaning and definition, namely: efforts in the form of orders, warnings, understanding, direction, guidance, coaching, assistance, explanation, examination, enlightenment of mind and spirituality, intelligence, teaching, and purification soul. The series of activities are related to the optimization of all potential in mankind, namely: spiritual, physical, intellectual, psychological, and social potential.

He word 'spiritual' comes from the word spirit, namely from the Latin "spiritus" which means breath, or the verb "spirare" which means to breathe. If one studies the origin of the word, having breath means having spirit. A person having spirituality means having ties to things that are spiritual or psychological in nature rather than materialistic and physical things. Spiritual is self-enlightenment or self-awakening in reaching the purpose of life and the meaning of life. Spiritual is a substantial part of a person's overall wellbeing and health. ${ }^{34}$ Spiritual is an effort to find meaning, goals, and guidelines in living life. Even in the Western concept, Ellison argued that spirituality is also possessed by people who do not believe in God. ${ }^{35}$ The essence of spirituality is belief related to the relationship between a person and God. ${ }^{36}$ Although spirituality is very difficult to define, I found the characteristics of spirituality that most people could agree on, namely spirituality being the state of human life and its relationship with God. If one operational definition is drawn, spirituality is the motivation of a person who is made into the most fundamental principles and principles of final judgment, namely the main argument given for choice in life.

The phenomena of spiritualism have often referred to the rise of the new age which is characterized by a spiritual approach to seeing all events. According to Rachman, spiritualism has become the foundation of human life in the

${ }^{32}$ Mahmud Yunus. Kamus Arab-Indonesia, 36

${ }^{33}$ Muhammad Naquib al-Attas. Konsep Pendidikan dalam Islam. (Bandung: Mizan, 1988), 61

${ }^{34}$ Fontana \& David. Psychology, Religion, and Spirituality. (British: Psychological Society and Blackwell Publishing, 2003), 87

${ }^{35} \mathrm{CW}$. Ellison, "Spiritual Well Being: Conceptualization and Measurement." Journal of Psychology and Theology, Vol. 11, No. 3, 2002, 2

${ }^{36}$ Achir Yani, Buku Ajar Aspek Spiritualitas, (Jakarta: Widya Medika, 2000), 34 
East for thousands of years, but that motivation is increasingly fragile and shrinking due to the development of rational Western science and technology, while spiritualism is not only about mind but also relations between mind and spirit. ${ }^{37}$ Muhammad Umar al-Syaibany argued that the highest values in human life are spiritual or religious and ethical values because both of these have become guidelines and principles for other values. ${ }^{38}$ In the concept of secular liberals, humans consist of body and spirit. The spirit in question is the power of thought, which is influenced by the five senses or that is related to materialistic things, because their studies are limited to the brain in the physical form. ${ }^{39}$ However, this is not in accordance with the Islamic concept of human nature. In Islamic teachings, it is mentioned that every human has the potential and basic spiritual needs, both religious and non-religious.

This spiritual education is related to the potential of al-nafs, al-'aql, al-qalb, and al-ruh contained in human beings. According to Sa'id Hawwa, this potential can only be developed through a 'journey' to Allah SWT. The journey requires knowledge of the nature and substance of humanity. On the other hand, someone who does not want to take the 'journey' to Allah SWT will not know much about the al-nafs and its substance. In other words, humans will not be able to know much about the creator so long as he does not want to travel to Allah SWT. Here lies the difference between the aqliyyah faith which is theoretical and the zauqiyyah faith (feeling). ${ }^{40}$ Spiritual education is a process of shaping a personality based on emotional and spiritual intelligence which relies on the aspect of self. ${ }^{41}$ The balance of using emotional and spiritual intelligence will create perfect human beings, and at the same time being able to become an ummah with individual and social piety. According to Hasan al-Bana, spiritual education is tarbiyah ruhiyah which aims to strengthen the path of tairuf. ${ }^{42}$ The point is to strengthen the soul and spirit, anticipate customs and traditions, continuously maintain good relations with Allah, and always ask for His help, without putting aside one's activities in life in the world. In other words, one always maintains a balance between his needs in the world and in the hereafter.

According to Sa'id Hawwa, the aim of spiritual education is to create a perfect

\footnotetext{
${ }^{37}$ Budhy Munawar Rachman, Islam Pluralis (Jakarta: Paramadina, 2001), 165

${ }^{38}$ See M. Mujib Djumransjah, (ed.), Filsafat Pendidikan: Telaah Tujuan dan Kurikulum Pendidikan, (Malang: Kutub Minar, 2005), 43

${ }^{39}$ Zainuddin, Pendidikan Agama Islam, 19

${ }^{40}$ Sa’id Hawwa, Pendidikan Spiritual, terj. Abdul Munip, (Yogyakarta: Mitra Pustaka, 2006), 12

${ }^{41}$ Abdul Munir M., Nalar Spiritual Pendidikan Solusi Problem Filosofis Pendidikan Islam (Yogyakarta: Tiara Wacana, 2002), 73

${ }^{42}$ See dalam Triyo Supriyatno, Humanitas Spiritual Dalam Pendiikan, (Malang: UIN Malang Press, 2009), 124
} 
human being, namely one who always fulfills the obligations of his ubudiyyah, as well as being very generous in everything when interacting with each other. On that basis, the community order is created that upholds the values of love, tolerance, respect, and morality. ${ }^{43}$ Meanwhile, according to al-Ghazali, the purpose of spiritual education is not to seek wealth, achievement, or material position, but to get closer to Allah SWT. Because if the purpose of education is directed toward other goals rather than getting closer to Him, then it can cause damage, hatred, malice, arrogance, and hostility. ${ }^{44}$ Thus, it can be concluded that spiritual education is education based on experiences carried out consciously to direct the spirit to keep going in accordance with nature, namely to believe in Allah SWT and develop divine potential until one reaches the peak of the faith in Him, so that his soul can encourage his physical activities or daily actions to always run in accordance with the law of Allah.

\section{THE MESSENGER WITH SPIRITUAL EDUCATION MISSION}

Muhammad (pbuh) is a role model for all humanity. He is the living Qur'an. It means that Muhammad emanated in a concrete manner the teachings of the Qur'an. He was the recipient of the first revelation and the main executor of all the commands of Allah SWT and abandoned all his prohibitions. Therefore, humanity can observe Islamic teachings by imitating each of his behavior. $^{45}$ There are reasons why Muhammad (pbuh) is placed as the best reference for studying spiritual education in Islam, namely: first, Muhammad as 'teacher'. Abu Ya'la narrated a hadith that when Muhammad (pbuh) entered the mosque in which there were two groups. The first group were praying, doing $d h i k r$, and prayer, while the second studying and discussing a problem. Muhammad (pbuh) apparently joined the second group. On this occasion, Muhammad (pbuh) said, "God has sent me as a teacher (ba'atsani rabbi mu'alliman)." 46

Second, Muhammad (pbuh) not only had deep understanding and expertise about religious, social, economic, political, legal, psychological, and cultural sciences, but he also had a perfect personality, as well as excellent teaching skills. This indicates that Muhammad (pbuh) was also a professional educator. ${ }^{47}$

${ }^{43}$ Hawwa, Pendidikan Spiritual, 13

${ }^{44}$ Al-Ghazali, Ihya' 'Ulumuddin, (Kairo: Dar al-Kutub al-Arabiyah, tt)

${ }^{45}$ Muhammad Syafii Antonio. Muhammad Saw: The Super Leader Super Manager, 195

${ }^{46}$ Ziauddin Alavi. Pendidikan Islam Pada Awal Pertengahan. Translated by Abuddin Nata, from the original title Islamic Education in Middle Age, (Bandung: Angkasa, 2002), 67

${ }^{47}$ For more details about the teaching method applied by Prophet Muhammad SAW, read Muhammad Syafii Antonio, Muhammad Saw: The Super Leader Super Manager, (Jakarta: Tazkia Publising, 2009) 
Third, Muhammad (pbuh) had established an educational institution in Dar al-Arqam ${ }^{48}$ and other places secretly, while in Mecca, and educational institutions openly like Suffah ${ }^{49}$ and Khuttab ${ }^{50}$, when in Medina. These efforts show that Muhammad (pbuh) had a great attention to the development of Islamic education. Fourth, Muhammad (pbuh) is regarded as the most successful prophet and leader of the divine mission, which transforms the Jahiliyah (ignorant) people into more civilized, from being astray to being faithful, from darkness to light, and from moral decline to noble morality. This success is closely related to his success in bringing the mission of education to life.

During the peak of the 'Quraysh ignorance' and pressure, Prophet Muhammad (pbuh) made a khalwa (retreat) ${ }^{51}$ in the Hira' Cave. At that cave, he found a good place to identify problems, and explore the thoughts that raged inside

${ }^{48}$ In the fifth year of Muhammad's Prophethood, a home belonging to al-Arqam ibn al-Arqam al-Makhzumi served as the center of education. He was the eleventh person who embraced Islam. In that house, there were many people who converted to Islam which reached 40 people, the last being Umar bin Khattab. At least there are three reasons the Prophet SAW chose the house of al-Arqam, among others: (1) Al-Arqam took shelter under the Bani Makhzum clan which was the traditional enemy of the Banu Hashim. For this reason, it would be very difficult for the unbelievers to imagine that the Prophet who came from Banu Hashim clan actually used the home of a member of the Bani Makhzum clan; (2) At that time al-Arqam was very young, only 16 years old, so the assumption of the infidels would be difficult to understand how a home belonging to a young person would be made a center of da'wah by the Prophet; (3) Al-Arqam's convert to Islam was still unknown to anyone except by Muslims at that time. See al-Hamid al Husaini. History of the Life of the Great Prophet Muhammad, (Bandung: Pustaka Hidayah, 2009), 294; and Munir Muhamad Ghadlban. Fiqh al Sirah al Nabawiyah. (terj.) Jakarta: Rabbani Press. 1992, 324-341

${ }^{49}$ Suffah is a room or building that is connected to the mosque. Or also called al zilla which is a seat on the edge of a mosque and under the same roof with a mosque or in the porch of the mosque. Those who live in this condition are called ahl al suffah. See Antonio, Muhammad Saw, 196

${ }^{50} \mathrm{Kuttab}$ is a kind of learning place that originally emerged in the Islamic world. At first the Kuttab functioned as a place to provide reading and writing lessons for children. Over time, the study of the Qur'an was also taught there. See Ensiklopedi Islam. Vol III. (Jakarta: Ichtiar Baru van Hoeve, 2002), 86

${ }^{51}$ The purpose of khalwa here must not be understood as the behavior of some people who are wrong and deviant. They understand it as an act of completely abandoning association with humans by living in caves. This action is contrary to the instructions of the Prophet and the practice of his companions. The purpose of khalwa here serves as antodote to improve the situation. Because as antidote, this should not be done except with certain levels as necessary. Otherwise, this will be a disease that must be avoided.

While in exile, he often dreamed that everything ended in reality. As for his dreams, it was a true dream which was the precursor of revelation. This happened for approximately six months. See Muhammad Husain Haekal. The Life History of Muhammad, (Jakarta: Pustaka Jaya. 2008), 139; and Muhammad Ali Shabban. The Holy Example of the Prophet's Family, 37. And see also Muhammad Sa'id Ramadhan al Buthy. Sirah Nabawiyah: Analisis Ilmiah Manhajiah Sejarah Pergerakan Islam di Masa Rasulullah Saw. Jakarta: Rabbani Press. 2010), 57 
him. The purpose of khalwa in the Hira' Cave was to identify problems that occurred in the Meccan community, and to find solutions. In addition, he also gained peace of mind and the antidote to the desires of the lonely heart, and reached the highest level of the secrets of the universe. At the age of 40 years ${ }^{52}$, Muhammad (pbuh) received the first revelation. Gabriel embraced the body of the Prophet when he was scared. ${ }^{53}$ Al-Buthy explained that the fear and anxiety felt by Prophet Muhammad was evident that he had never at all "longed for the message" he was revealed to. Also, this phenomenon of revelation does not come together or perfect whatever crossed his mind. However, the revelation appeared surprisingly in his life without ever being imagined before. Fear and anxiety will never be experienced by those who have have spent time contemplating and thinking profoundly of an aqeedah which is believed to be his da'wah. ${ }^{54}$

The main education mission carried out by Muhammad (pbuh) is contained in the Qur'an, for example in the QS Al Anbiya '[21] verse 107, QS. Saba '[34] verse 28, and QS. Al-Ahzab [33] verse 21. In fact, the mission is attached to the goals and ideals of the Islamic teachings itself, which is to bring rahmatan lil 'alamin (mercy to all creatures), according to the following word of God:

Interpretation: "And We have not sent you, [O Muhammad], except as a mercy to the worlds." 55

Imam al-Maraghi in his tafseer (commentary) said, "That the meaning of the verse means: And we did not send you, but to be a mercy to the universe, is that I did not send you, Muhamma, with this Qur'an, and various parables of the religious and legal teachings that became the basis of reference for achieving happiness in the world and the hereafter, but in order to become a mercy and guidance for them in all matters of the life of the world and the hereafter." 56

${ }^{52}$ Confirmation of a common tradition, namely that the prophets were sent to become apostles when they turned 40 years old. So that, on the eve of Ramadan (perhaps the 17th night) the angel Gabriel descended on him carrying prophetic news in surat al Alaq verses 1-5 as an opening and introduction to the burden of the treatise he must bring to all mankind. See Abu Bakar Jabir Al Jazairi. Muhammad, My Beloved Prophet, (Jakarta: Qisthi Press. 2007), 96

${ }^{53}$ Gabriel's action was a therapy to eliminate all feelings of fear buried deep in his heart. The tight hug was able to make the Prophet Muhammad surprised even though he then replied. A reflex that symbolizes courage. After the incident, the Messenger of Allah never feared, let alone hesitated in spreading Islam to all corners of the world.

${ }^{54}$ Muhammad Sa'id Ramadhan al Buthy. Sirah Nabawiyah, 63

${ }^{55}$ QS. Al Anbiya' (21): 107

${ }^{56}$ Imam Al Maraghi. Tafsir Al Maraghi, Jilid VI. (translated version) Beirut: Dar al Fikr, $\mathrm{tt}, 78$ 
According to Shihab, with the blessing, the inner needs of every human being are fulfilled so that they can achieve peace, tranquility, and recognition of their form, talent, rights, and nature, eventually creating quality human resources. ${ }^{57}$ According to al-Razi in Tafsir al-Razi, the blessing of Prophet Muhammad is for the wider community, and whoever follows his teachings, will also get his mercy. But on the contrary, if one does not follow him, the grace of their soul will disappear. The other nature of grace is a blessing for all human groups who are hostile to it. Although the Prophet was insulted and hurt, he always prayed for good for them. ${ }^{58}$ Meanwhile, when interpreting this verse, Hamka said that every teaching of Prophet Muhammad is a system that brings happiness and spiritual delights to all humanity, the message of Muhammad (pbuh) that came to this world, includes 3 blessings namely: (1) Grace in freedom of thought, so that the mind is not afraid of the progress of the times; (2) Grace of harmony and balance of human needs, namely: physical and spiritual, world and the hereafter; (3) Grace of unity and brotherhood to become a great and civilized nation. ${ }^{59}$

Muhammad (pbuh) was raised to be a mercy for mankind, animals, plants, even all other creations of Allah SWT. Muhammad (pbuh) carried out teachings about the glory of mankind, equality, unity, and guidelines for relations between fellow humans, relations between religious adherents, even relations with nature. He taught humans about justice, brotherhood, peace, helping each other, family principles, neighborhood and community guidelines, etc. He forbade humans to harm anyone, even animals. Muhammad (pbuh) also taught humans to make use of the environment and preserve it, even in conditions of war, he forbade the destruction of plants without benefits.

Interpretation:"And We have not sent you except comprehensively to mankind as a bringer of good tidings and a warner. But most of the people do not know." ${ }^{60}$

The Qur'an surah Saba' verse 28 reveals the prophethood and apostolate of Muhammad (pbuh), by asserting that Allah has actually sent Muhammad (pbuh) by bringing clear proof, namely the Qur'an. According to Thabathaba'i, the word "kaffatan" means blocking. Therefore, he explained the content of the verse means: "We do not send you unless it functions as a very superior

${ }^{57}$ M. Quraish Shihab, Tafsir Al-Misbah Vol. II, 145

${ }^{58}$ When Prophet Muhammad was insulted and hurt by his enemies, he prayed, "O Allah, give guidance to my people, because they did not know," See: Muhammad bin Abi Bakr ar-Razi, Tafsir Al-Razi, (Beirut: Dar Al-Fikr, 1990), 98

${ }^{59}$ Hamka, Tafsir Al-Azhar Juz 17, (Jakarta: Panjimas, 1990), 45

${ }^{60}$ QS. Saba' [34]: 28 
barrier to humans so that they do not do various iniquities." This is also supported by the following sentence: "basyiran wa nadziran". He explained that the word "kaffah" means the condition of all humans. So, this verse reveals the message of Muhammad (pbuh) for all humanity. This interpretation is in line with the previous verse, namely the role of Muhammad (pbuh) being sent to bring mercy to all worlds. Thabathaba'i wrote that, "the commissioning of the Prophets is a necessity and takes care of His servants and leads them to happiness. But most humans do not know in the sense that they do not know that the limited source of sending apostles is only God Almighty." ${ }_{1}$

Meanwhile, according to Hamka, all human beings in this world are the goal of Muhammad's educational mission which does not differentiate ethnicity, nation, language, culture, regional boundaries, and skin color. The verse means entertaining, as well as threatening. Entertaining means to give good news about happiness in the world and in the hereafter and out of the darkness of ignorance toward the truth of real faith. Threatening means giving a warning to anyone who does not obey His teachings, his life will be dark and astray. ${ }^{62}$ In fact, Muhammad (pbuh) was resurrected in order to carry out the mission of spiritual education, namely to perfect the akhlâq.

Interpretation: "There has certainly been for you in the Messenger of Allah an excellent pattern for anyone whose hope is in Allah and the Last Day and [who] remembers Allah often." ${ }^{63}$

The word uswah in the verse means the role model. According to azZamakhsyari, the example in the verse has two possible purposes, namely: (1) in terms of the personality of Prophet Muhammad in totality; (2) in the sense that is contained in his personality, aspects that deserve to be emulated. However, most scholars agree on the first opinion. ${ }^{64}$ Meanwhile, al-Raghib in Tafseer Ruhul Bayan, interpretes the word uswah to be the same as al-qudwatun (follow), which is a condition found in human beings that can be followed by others good or bad. Meanwhile, the word hasanah is an example of good words and behavior. The word is based solely on a clean soul, namely that the Messenger of Allah in his soul has uswatun hasanah that can be emulated and followed. ${ }^{65}$

Al-Qurtubi revealed that in matters of religion, exemplary is an obligation as long as there is no evidence to show that it is a suggestion, but worldly

${ }^{61}$ M. Quraish Shihab, Tafsir Al-Misbah, 234

${ }^{62}$ Hamka, Tafsir Al-Azhar Juz 22, (Jakarta: Panjimas, 1990), 34

${ }^{63} \mathrm{Al}$ Qur'an Surat Al Ahzab (33): 21

${ }^{64}$ Shihab, Tafsir Al-Misbah, 242

${ }^{65}$ Syekh Ismail Al-Burusyiu. Tafsir Ruhul Bayaan. (Beirut: Darul Fikri, t.th.), 156 
affairs become a recommendation (not an obligation). Some scholars say that in worldly affairs, Muhammad (pbuh) has fully surrendered to experts in their respective fields, so that the example referred to in this verse is not in aspects related to worldliness. ${ }^{66}$ Apart from these differences of opinion, 'Abbas Mahmud al-Aqqab revealed that there are 4 types of people, namely: thinkers, workers, artists, and worshipers. It is rare to find humans who have these 4 types at the same time accumulate in themselves. However, for those who study and understand Prophet Muhammad personally, he will find that the four types are integrated with the highest rank so that humans can emulate all the commendable qualities in him. ${ }^{67}$

In a hadith, it is also stated clearly that the main mission carried out by Muhammad (pbuh) is to perfect akhlậ.

"Abu Hurairah narrated that the Messenger of Allah (pbuh) said: "Verily I am sent to perfect the glory of akhlạq." ${ }^{\prime}$

It means that Muhammad (pbuh) was resurrected in his prophetic body not to encourage people to become rich, smart politicians, and proficient at being a symbol of the advance of human thought at that time. Because at that time all the skills had been around, all had happened. Only that they were not found in the rich, the power-holders and smart people at that time because their behavior was no longer noble. With regard to the resurrection of Muhammad (pbuh), in fact the educational ontology he demonstrated is the changes "within" the students. That, God will not change the condition of a people until they are willing to change what is inside them. ${ }^{69}$ Therefore, some of the theories put forward by many education experts do not seem to direct on the real ontology. ${ }^{70}$ Reading these definitions makes it unable to be used

${ }^{66}$ Shihab, Tafsir Al-Misbah, 243

${ }_{67}$ 'Abbas Mahmud al-AAqab, Abqariyyah Muhammad, (Beirut: Dar al-Fikr, 1970)

${ }^{68}$ HR. al-Baihaqi. Sunan al-Baihaqi, Juz 2, 472, dalam al-Maktabah al-Syamilah

${ }^{69}$ Q.s.al-Dzâriyât: 11

${ }^{70}$ For example, John Dewey said, education is a process of forming intellectually and emotionally basic human skills. J.J. Rouseau said, education is a provision to us what we do not need in childhood, but we need it as adults. M.J.Langeveld said, education is every effort made to influence and guide children toward maturity, so that children are deft in carrying out their own life duties. According to him education only takes place in an atmosphere of association between adults (or those created by adults such as: schools, model books and so on) with immature people who are directed to achieve educational goals. John S. Brubacher said education is a reciprocal process of each individual human being in order to adapt itself to nature, with friends and with the universe. Kingsley Price suggests that education is a non-physical process of cultural elements that are nurtured or developed in caring for young people or in adult learning. Mortimer J. Adler said, education is a process in which all human abilities (talents and abilities acquired) that can be influenced by habituation, are perfected by good habits through means that are artistically created and used by anyone to help others or 
as the main standard, and the theory cannot be applied, because all of these definitions show that the experts still disagree or differ in opinion.

Thus, the mission of education should refer to the condition where Muhammad (pbuh) was first resurrected. Some facts abot the Quraysh at that time were: first, from the perpective of their knowledge they were very well established, which was illustrated by the height their literary works as a result of their reflection and creativity; second, from an economic standpoint, the Arabs at that time were already in progress. It coincided with the city of Mecca when it became a city and the center of trade traffic. Evidently Muhammad (pbuh) never made his own currency but used the existing currency. And third, from the socio-political side, the Arabs at that time were well established and there were already social and political strata. The proof is that Bani Hasyim emerged as the best social group and there were leaders among them. That means the main mission of the teaching of Muhammad (pbuh) is not to inspire the advance of science, economy and social politics, because even without the resurrection of Muhammad (pbuh), all of that could occur and be organized by itself, especially those that were worldly in nature. What did not exist there at that time was the virtues. There was no civilization in all established practices at that time. The establishment of knowledge, economy, social politics is not to respect the existence of oneself for humans, but rather it is used as a tool to oppress and demean others, for example in this case of the most victimized members of the society, women. For example, an extract of the text from Khatbah Wada' on what Muhammad (pbuh) delivered.

"O people listen to what I want to say. Maybe after this year, I will not see you again in this place forever ... O mankind, in fact your blood and possessions are sacred to you (that is, it may not be tainted by anyone) like the holy days and months at your country. In fact, all forms of behavior and acts of the ignorant shall never occur again. Such an ignorant act of reprisal which I first declared to be stopped is an act of retaliation for the death of Ibn Rabi'ah Ibn al-Harith." ${ }^{71}$

when examined from the aspect of education, Muhammad (pbuh) has actually succeeded in educating the people from the colonies of the Jahiliyah, spiritual ignorance, and intellectual weakness which includes culture of silence dan structural poverty. ${ }^{72}$ Therefore, the only prophet who sparked his educational

themselves itself achieves the set goals, namely good habits. See Rupert C. Lodge, Philosophy of Education (New York: Harer \& Brothers, 1974), 23

${ }^{71}$ This Semon text was quoted from Shahih Muslim and Shahih Bukhari. See also Al Nadawi. Shahih al Sirah al Nabawiyyah, 550

${ }^{72}$ Abdurahman Mas'ud. Menuju Paradigma Islam Humanis. Yogyakarta: Gama Media. 
mission to glorify akhlậ ${ }^{73}$ is Muhammad (pbuh). It does not mean that the Islamic teachings are against anything other than akhlâq. But there is priority, there are targets that are very clear and logical and conditional. From here, the history of the revelation of verses, which are now contained in the Holy Qur'an, indicated that 13 years of the teaching of Muhammad (pbuh) concerns faith. If this faith is like the explanation above, then the most priority is the change of self, because that self is faith as the substance of the nature of believers who possess the rabbaniyyah character.

\section{IMPROVING SPIRITUAL ELEMENTS}

In QS Luqman: 12-19 which contain the advice of Luqman al-Hakim about the mission of education which must be delivered by parents in particular and educators in general. In the verse, the concept of Islamic education contains three main points of material or guidance of religion: aqeedah, sharia and akhlậ. ${ }^{74}$ The main discussion about the mission of spiritual education is found in verses 12-14 below.

Interpretation: "And We had certainly given Luqman wisdom [and said], "Be grateful to Allah ". And whoever is grateful is grateful for [the benefit of] himself. And whoever denies [His favor] - then indeed, Allah is Free of need and Praiseworthy. And [mention, O Muhammad], when Luqman said to his son while he was instructing him, "O my son, do not associate [anything] with Allah. Indeed, association [with him] is great injustice. And We have enjoined upon man [care] for his parents. His mother carried him, [increasing her] in weakness upon weakness, and his weaning is in two years. Be grateful to Me and to your parents; to Me is the [final] destination." ${ }^{75}$

The verse implies that Luqman as an educator (parent and teacher) has been blessed with a wisdom by Allah, therefore he is grateful for that gift. As an educator who is blessed with wisdom, he can carry out his mission in educating his children to always be grateful and worship Allah. So, as an educator instilling spirituality with his students, he himself must be provided with wisdom (wisdom). How is it possible to teach their students to pray, if their educators rarely pray? How is it possible to teach manners to their students, if the educators themselves are savages? It is impossible teach

2003,188

${ }^{73}$ Akhlậq the concrete form is a believer in the heart, while mind is the five senses that can actively function if the one inside it functions.

${ }^{74}$ M. Quraish Shihab, Tafsir Al-Misbah, 11 and 140

${ }^{75}$ QS. Luqman [31]: 12-14 
sincerity, if the educator loves to show off. An educator with wisdom will be fully confident about his actions; he believes, speaks, and acts on the basis of the truth. Therefore, al-Maraghi referred to it an ingenuity and wisdom. ${ }^{76}$

The educator has two characteristics, namely teacher of science and teacher of wisdom. The science teacher is oriented to the exoteric aspects of zhâhir knowledge, while the teacher of wisdom is more oriented to the esoteric aspects (knowledge or inner elements). Therefore, by integrating these two types of teacher characteristics, it will guide students towards the gate of Allah. There are two gates that humans will enter namely the gate of the creature and the gate of Allah, and the gate of the world and the gate of the hereafter. It's impossible to uncover the secret of the final gate, if you don't understand the first gate. ${ }^{77}$ Shaykh 'Abd al-Qâdir al-Jîlâniy has revealed the importance of combining intellectual and spiritual education. Intellectual education takes place in Madrasa, while spiritual education is placed in zawiyah or ribath. Both types of education models have the same objectives, namely, promotion amar ma'rûf (promotion of virtues) and nahi munkar (prevention of vice). Therefore, in learning activities, the involvement of the psychological (mental) readiness of students has becomes an important aspect of developing potential in intellectual and spiritual development. The obligations or adab that must be applied by every educator in instilling spirituality with his students, are among others: (1) educators should teach and give advice only because Allah, treat the students with love so that a teacher is like their own parent; (2) If educators know the sincerity of their students, then they must not give them relief, but must oblige them to live the commandments of Allah and stay away from His prohibitions; (3) educators should always pay attention to the behavior of their students. If they their students violate the Islamic teachings, they must advise them and them him not to repeat it; (4) Educators should teach their students to always uphold the principle of virtues and stay away from vile actions. ${ }^{78}$

Referring back in the main discussion, the mission of the spiritual education that was instilled by Luqman is found in verses 16-17, which teaches the relationship between man and Allah, and relations between humans.

Interpretation: "[And Luqman said], "O my son, indeed if wrong should be the weight of a mustard seed and should be within a rock or [anywhere]

\footnotetext{
${ }^{76}$ al-Maraghi, Tafsir al-Maraghi, 87

77 Habib Abdullah Zakiy al-Kâf, Ajaran Tasawuf Syaikh 'Abd al-Qâdir al-Jîlâniy: Petunjuk Jalan Menuju Ma'rifatullâh, (Bandung: Pustaka Setia, 2003), 241

${ }^{78}$ Abd al-Qâdir Al-Jîlâniy, Al-Gunyah li Thâlib Tharîq al-Haqq, juz II (Beirut: alMaktabah al-Sya'biyyah, tth.), 168
} 
in the heavens or in the earth, Allah will bring it forth. Indeed, Allah is Subtle and Acquainted. O my son, establish prayer, enjoin what is right, forbid what is wrong, and be patient over what befalls you. Indeed, [all] that is of the matters [requiring] determination." 79

According to Al-Maraghi, the verse describes retaliation or consequences for every human act, good or bad. Good charity will get the consequences of good, too (reward), so bad deeds will also get sin. There is no action that is unknown to Allah SWT. Even though the act is carried out even in the most hidden place, the weight of the act is only a grain of mustard, surely Allah would know, find and reply later on the Day of Judgment. ${ }^{80}$ Quraish Shihab also revealed, the command of prayer in this verse means an order to establish prayer with the right nature and manner. Whoever does it means having to submit to Him, which will have implications for the growth of spiritual awareness, in order to control the soul to uphold the amar ma'ruf nahi munkar (promotion of virtues) nahi munkar (prevention of vice). According to him, prayer will be able to guarantee the continuity of monotheism and divine existence in the hearts of students. ${ }^{81}$

The elements of spiritual education are very comprehensive that must be built to develop a person as a whole, based on the Qur'an and sunnah, with the aim of the applying the Islamic teachings that are rahmatan lil alamin, with happiness oriented not only in the world but also in the hereafter. The stages and elements in spirituality education contained in the Luqman Letter Verses 12-19 include: (1) aqeedah education and its material, (2) sharia education and its material, (3) moral and social education and its material. Whereas, the way to cultivate spirituality in students from the perspective of QS Luqman includes: (1) instilling divine values / monotheism by not associating partners with Allah, (2) fostering devotion to parents, (3) teaching students that every deed reciprocate, (4) command to worship, (5) introducing students to the manners of social life. In more detail, the application of spiritual education can be seen and studied in Surat al-Muzzammil verses 1-10 and 20.

Interpretation: "O you who wraps himself [in clothing], Arise [to pray] the night, except for a little Half of it - or subtract from it a little. Or add to it, and recite the Qur'an with measured recitation. Indeed, We will cast upon you a heavy word. Indeed, the hours of the night are more effective for concurrence [of heart and tongue] and more suitable for words. Indeed, for you by day is prolonged occupation. And remember

\footnotetext{
${ }^{79}$ QS. Luqman [31]" 16-17

${ }^{80}$ al-Maraghi, Tafsir al-Maraghi, 84

${ }^{81}$ M. Quraish Shihab, Tafsir al-Misbah, 136
} 
the name of your Lord and devote yourself to Him with [complete] devotion. [He is] the Lord of the East and the West; there is no deity except Him, so take Him as Disposer of [your] affairs. And be patient over what they say and avoid them with gracious avoidance." ${ }^{2}$

Interpretation of the verses 1-3 of Surat al-Muzzammil's according to Shihab is that the context of these verses are closely related to the command to establish the evening prayer. ${ }^{83}$ Al-Maraghi, also said that Allah SWT told Muhammad to pray at night. Muhammad (pbuh) was ordered to choose between one third (between 22:00 to 23:00), half (between 24:00 to 01:00), and two thirds of the night (between the hours of 2:00 to 3:00). ${ }^{84}$ Meanwhile, Hamka argued that Allah SWT ordered Muhammad to perform Qiyam prayer, by saying "wake up", or establish prayer, because, prayer must be established with full seriousness and self-awareness. The word "except a little" means to use a little of the night to rest, but the most use to do prayer. ${ }^{85}$ Believers who have a high level of faith will experience peace of mind. That belief does not come by itself, but can be achieved by getting used to worship, namely prayer that will bring about the soul's fortune. ${ }^{86}$ Peace and happiness of the soul is one of the characteristics that a person has spiritual intelligence. In addition, prayer is also a spiritual aspect because it contains high spiritual values, where one's heart will be calm and his stance will be strong and he will have a high sense of optimism. The nightly prayer that is established solemnly will make someone feel a strong relation with Allah SWT, so that trials and problems of life will be faced with patience, optimism and self-confidence. This will nurture and foster a stable, strong and dynamic mental attitude.

In verse 4 , in Tafsir Ibn Katsir, it is explained that the purpose of the verse is the command to read the Qur'an with tartil, which is to read the Qur'an in a good manner and slowly, because it will facilitate understanding and contemplating it. ${ }^{87} \mathrm{Al}$-Qurthubi said, the purpose of reciting the Quran in a slow manner, without rushing is that it should be accompanied by reflection on what the meaning of the recital is.$^{88}$ So, it can be concluded that the 4 th verse instructs us to read the Qur'an accompanied by tartil, namely by slowly and contemplating on its meaning, so that it can be understood and pervaded in the heart. The aspect of spiritual education contained in the 4 th verse is an

${ }^{82}$ QS. al-Muzzammil [73]: 1-10

${ }^{83}$ Shihab, Tafsir Al-Misbah, 404

${ }^{84}$ Al-Maraghi, Tafsir Al-Maraghi, 190

${ }^{85}$ Hamka, Tafsir Al-Azhar, 705

${ }^{86}$ Muhammad Bahnasi, Shalat Sebagai Terapi Psikologi, 68

${ }^{87}$ Al-Imam Abul Fida Isma'il Ibnu Katsir ad-Dimasyqi, Tafsir Ibnu Katsir, Translated by Abdullah, (Jakarta: Pustaka Imam Asy-Syafi'i, 2008), 126

${ }^{88}$ Al-Qurthubi, Tafsir Al-Qurthubi, 435 
effort to educate the heart through reading the Quran with tartil, which is not only slowly, but by understanding and living the meanings contained in it. So when reciting verses hints at the truth, one's conscience will certainly justify and tend to do good. On the other hand, if one reads verses about torture, they will think twice before doing it.

In verses 5-6, Al-Maraghi explained that the qiyamullail aims to establish and adjust between one's words and heart, and gather thoughts to observe the recital and understand it because time at night is calmer for the heart than during the day, because the daytime is the time to seek the interests of the life of the world, the business of man, and the noise of the sound. ${ }^{89}$ In verses 7-8, Al-Qurtubi argued that the verses are in the form of a command from Allah SWT to pray to Him by using al-Asma' al-Husna. ${ }^{90}$ Ibn Kathir also said that the purpose of the verses is to increase dhikr to Allah SWT, dedicate oneself and dependence on Him. ${ }^{91}$ So, it can be concluded that these verses explain the command to pray, think, and depend on hope only to Allah SWT. The verses confirm that $d h i k r$ can bring oneself cognizance (self awareness), "I am confronted by God", so that I can push myself consciously and responsibly to continue the dynamic mission of my life, which is to do good deeds. "Dhikr is not just a ritual but a beginning of the actual life journey. ${ }^{92}$ Dhikr and praying are both the means and self-motivation to show the face of a responsible person. Dhikr suggests a trip to return home and meet the One we love. It also fosters self-confidence because they have the intention or desire to give the best when they return later. Their stance is firm in carrying out the mandate without the slightest doubt. In verses 9-10 in QS al-Muzzammil, there is a command to be patient for what others say about you and about God. And there is also an order to stay away from them in a gracious way, namely by watching them, but stay away from them, meaning closing our eyes to their mistakes and not criticizing them. Thus, it can be concluded that the elements of spiritual education contained in Surat al-Muzzammil Verses 1-10 include: qiyamul lail or night prayer, reciting the Qur'an by means of tartil (slowly), getting used to dhikr, being patient, jihad fi sabilillah or fighting on the path of Allah, and always begging forgiveness from Allah SWT.

Elements of spirituality can be improved or developed in three steps, namely: first, try to uncover the "diseases" of the heart and try to identify and diagnose them. So that you can know what have covered your inner voice. The ultimate goal is the discovery of antidote that will create the birth of clarity

\footnotetext{
${ }^{89}$ Al-Maraghi, Tafsir Al-Maraghi, 192

${ }^{90}$ Al-Qurthubi, Tafsir Al-Qurthubi, 194

${ }^{91}$ Ibnu Katsir, Tafsir Ibnu Katsir, 843

${ }^{92}$ Toto Tasmara, Kecerdasan Ruhaniah, 17
} 
and purity of the heart, or commonly referred to as conscience, namely the return of an independent heart and free from radiation of heart "diseases". This process is the starting point of a spiritual intelligence. Because in general, conscience is used as a basis for spiritual intelligence. From here the beginning of spiritual intelligence begins to form. Humans have universal and ihsan (beautiful) values. Second, the next step concerns self-awareness, which is about the importance of mental dimensions. The scheme in constructing spiritual emotional intelligence systemically based on 6 pillars of faith, is through: building mentality by holding on to God's principles, working on duties and obligations sincerely, imitating wise leaders, continuing to learn to gain good knowledge, understanding the purpose of life, and knowing how to manage all the affairs of life. Third, a physical step carried out in a row and very systematically based on 5 pillars of Islam. This stage includes: (1) mission statement, and followed with intensive and continuous character formation; (2) character building, followed by self-control exercises; (3) selfcontrol. These three steps in developing spirituality will produce what is called personal strength or perfect human beings.

\section{CONCLUSION}

Spiritual education is a sacred, earnest, and noble struggle and formation to build character, soul, and personality, so as to create human beings who are ahsani taqwim, and vice versa to free him from things that hinder him. The mission of spiritual education carried out by Muhammad (pbuh) can be seen for example in Surat Al-Anbiya verse 107, Surat Saba' verse 28, and Surat AlAhzab verse 21. In Surat Al-Anbiya' verse 107, Allah affirms that Muhammad (pbuh) brought a vision as mercy for all worlds, not limited to humans, time and place. Whoever follows his teachings will receive His mercy. Surat Saba' verse 28 confirms that Allah SWT has sent Muhammad (pbuh) with evidence of truth, namely the Muhammad's (pbuh) teachings do not focus on Arabs only, but they include all humans, regardless of ethnicity, nation, language, race, and regional boundaries. Al-Ahzab verse 21 asserts that Muhammad (pbuh) is the only role model whom must be imitated by all humans, because in him all the praiseworthy qualities are found.

Meanwhile, the improvement of the elements of spirituality can be seen in the QS Luqman Verses 12-19 and Surat al-Muzzammil Verses 1-10. The stages of increasing spirituality in the QS Luqman Verses 12-19, include: (1) instilling tauheed values by not associating partners with Allah, (2) being filial to parents, (3) teaching students that every deed will reciprocate, (4) command to worship, (5) introducing students to the manners of social life. Elements 
of spiritual education contained in Surat al-Muzzammil Verses 1-10 include: qiyamul lail or night prayer, reciting the Qur'an in a tartil way, getting used to dhikr, being patient, jihad fi sabilillah or fighting on the path of Allah, and always praying and begging the forgiveness from Allah.

\section{BIBLIOGRAPHY}

Agustian, A. G. (2001). Rahasia Sukses Membangun Kecerdasan Emosi dan Spiritual, ESQ Way 165: 1 Ihsan, 6 Rukun Iman dan 5 Rukun Islam. Jakarta: Arga.

Ahmad, N. (2007). Tafsir Ayat-Ayat Pendidikan. Bandung: Marja.

Al-Abrasyi, M. A. (1993). Tarbiyyah Islamiyah (trans.). Jakarta: Bulan Bintang.

Al-Aqqab, 'A. M. (1970) 'Abqariyyah Muhammad. Beirut: Dar al-Fikr.

Al-Attas, M. N. (1988). Konsep Pendidikan dalam Islam. Bandung: Mizan.

Alavi, Z. (2002). Islamic Education in Middle Age (trans.). Bandung: Angkasa

Antonio, M. S. (2009). Muhammad Saw: The Super Leader Super Manager. Jakarta: Tazkia Publising.

Bahnasi, M. (2004). Shalat Sebagai Terapi Psikologi. Jakarta: Mizania.

Al-Burusyiu, S. I. (?). Tafsir Ruhul Bayaan. Beirut: Darul Fikri.

Al-Buthy, M. S. R. (2010). Sirah Nabawiyah: Analisis Ilmiah Manhajiah Sejarah Pergerakan Islam di Masa Rasulullah Saw. Jakarta: Rabbani Press.

Diansyah, A. (2018). Tersinggung, Siswa SMP Nekat Tikam Guru 13 Kali. Retrieved from https://daerah.sindonews.com/, accessed on 02/09/2018.

Al-Dimasyqi, A. A. F. A. I. K. (2008). Tafsir Ibnu Katsir (trans.). Jakarta: Pustaka Imam Asy-Syafi'i.

Djumransjah, M. M. (2005). Filsafat Pendidikan: Telaah Tujuan dan Kurikulum Pendidikan. Malang: Kutub Minar.

Dodi, L. (2018). Nilai Spiritulitas Sayyed Hossein Nasr dalam Manajemen Pendidikan Islam", Dirasat, Vol.4, Nomor 1.

Ellison, C.W. (2002). Spiritual Well Being: Conceptualization and Measurement. Journal of Psychology and Theology, Vol. 11, No. 3.

Fauzi, I. (2012). Manajemen Pendidikan ala Rasulullah. Yogyakarta: Ar-Ruzz Media.

Fontana \& David. (2003). Psychology, Religion, and Spirituality. British: Psychological Society and Blackwell Publishing. 
Ghadlban, M. M. (1992). Fiqh al Sirah al Nabawiyah (trans.). Jakarta: Rabbani Press.

Ghazali, (?). Ihya' 'Ulumuddin. Kairo: Dar al-Kutub al-Arabiyah.

Haekal, M. H. (2008). Sejarah Hidup Muhammad. Jakarta: Pustaka Jaya.

Hamka, (1990). Tafsir Al-Azhar. Jakarta: Panjimas.

Harto, K. \& Abdurrahmasyah. (2009). Metodologi Pembelajaran Berbasis Aktive Learning: Arah Baru Pembelajaran PAI di Sekolah dan Madrasah. Palembang: Grafika Telindo Harto.

Hawwa, S. (2006). Pendidikan Spiritual (trans.). Yogyakarta: Mitra Pustaka.

Husaini, A. H. (2009). Riwayat Kehidupan Nabi Besar Muhammad Saw. Bandung: Pustaka Hidayah.

Jalaluddin, (2003). Teologi Pendidikan. Jakarta: PT. Raja Grafindo Persada.

Jazairi, A. B. J. (2007). Muhammad, My Beloved Prophet. Jakarta: Qisthi Press. 2007.

Jîlâniy, A. Q. (?). Al-Gunyah li Thâlib Tharî̀ al-Haqq, juz II. Beirut: al-Maktabah al-Sya'biyyah

Kâf, H. A. Z. . (2003). Ajaran TasawufSyaikh 'Abd al-Qâdir al-Jîlâniy: Petunjuk Jalan Menuju Ma'rifatullâh. Bandung: Pustaka Setia.

Kartanegara, M. (2006). Menyelami Lubuk Tasawuf. Jakarta: Penerbit Erlangga.

Kurniawan, S. (2013). Dikotomi Agama dan Ilmu dalam Sejarah Umat Islam dan Kemungkinan Pengintegrasiannya. Fikrah, Vol.1, Nomor 1.

, (2017). Pendidikan Karakter dalam Islam: Pemikiran Al-Ghazali tentang Pendidikan Karakter Anak Berbasis Akhlaq al-Karimah. Tadrib, Vol.3, Nomor 2 .

Latipah, I. (2016). Implementasi Metode Al-Hikmah, Al-Mau'idhah AlHasanah, dan Al-Mujadalah dalam Praktik Pendidikan. Jurnal Ilmiah Mitra Swara Ganesha, Vol. 3 No. 2.

Lodge, R. C. (1974). Philosophy of Education. New York: Harer \& Brothers.

Maqdisi, S. (2007). Nabi Muhammad Buta Huruf atau Genius? (Mengungkap Misteri Keummian Rasulullah). Jakarta: Nun Publisher.

Maraghi, A. M. (1993). Tafsir Al-Maraghi (trans.). Semarang: PT. Karya Toha Putra.

Masbur, (2016). Integrasi Unsur Humanisasi, Liberasi, dan Transedensi dalam Pendidikan Agama Islam. Jurnal Edukasi, Vol.2, Nomor 1. 
Mas'ud, A. (2003). Menuju Paradigma Islam Humanis. Yogyakarta: Gama Media.

Muhajir, A. (2011). Ilmu Pendidikan Perspektif Kontekstual. Yogyakarta: ArRuzz Media.

Mujib, A. \& Mudzakir, J. (2006). Ilmu Pendidikan Islam. Jakarta: Prenada Media.

Munir, M. A. (2002). Nalar Spiritual Pendidikan Solusi Problem Filosofis Pendidikan Islam. Yogyakarta: Tiara Wacana.

Nata, A. (2010). Ilmu Pendidikan Islam. Jakarta: Prenada Media.

Nadwi, A. A. H. (2006). Shahih al-Sirah al-Nabawiyyah (trans.). Sleman: Mardhiyah Press.

Qurthubi, I. (2009). Tafsir Al-Qurthubi. Jakarta: Pustaka Azzam.

Rachman, B. M. (2001). Islam Pluralis. Jakarta: Paramadina, 2001.

Razi, M. A. B. (1990). Tafsir Al-Razi. Beirut: Dar Al-Fikr.

Shihab, M. Q. (1999). Membumikan al-Qur'an: Fungsi dan Peran Wahyu dalam Kehidupan Masyarakat. Bandung: Mizan.

-------, (2002). Tafsir al-Misbah Pesan Kesan dan Keserasian al-Quran. Jakarta: Lentera Hati.

Supriyatno, T. (2009). Humanitas Spiritual Dalam Pendiikan. Malang: UIN Malang Press.

Tonapa, J. B. (2018). Tak Terima Ditegur, Siswa SMP Aniaya Gurunya. Retrieved from https://daerah.sindonews.com/. Accessed on 02/092018.

Yani, A. (2000). Buku Ajar Aspek Spiritualitas. Jakarta: Widya Medika.

Yunus, M. (?). Kamus Arab-Indonesia. Jakarta: PT. Hidakarya Agung.

Zohar, D. \& Marshal, I. (1995). SQ: Spiritual Intelligence: The Ultimate Intelligence. Great Britain: Bloomsburry.

Zulkifli, S. (2018). Ini Kebohongan Alif, Siswa Pengeroyok Guru SMK 2 Versi Teman Kelas. Retrieved from http://news.rakyatku.com/. Accessed on $04 / 09 / 2018$

www.bkkbn.go.id/, diakses pada 11/09/2018

www.bnn.go.id/, diakses pada 12/09/2018

www.kpai.go.id/, diakses pada 12/09/2018

www.bankdata.kpai.go.id/, diakses pada 01/09/2018

www.sobatmuda.multiply.com//, diakses pada 11/09/2018 
